\title{
Are University Mergers a Solution for the Problems of Romanian Higher Education Nowadays?
}

\author{
Adrian Hatos \\ University of Oradea, Faculty of Social-Humanistic Sciences, 1 Universității St., \\ 410087, Oradea, Romania, \\ Center for Higher Education Research and Development, Debrecen University \\ ahatos@gmail.com
}

\begin{abstract}
This article discusses the timeliness of university mergers against the background of the crisis in Romanian higher education. It includes a summary review of international experiences while underlining the evaluation of the net results of the mergers and it shows that, in drafting and implementing such initiatives, a lot of precaution is needed, given that worldwide results are rather ambiguous. Finally, it discusses a number of evolution scenarios for the mergers in Romania and offers policy recommendations in the field.
\end{abstract}

Keywords: University merger, higher education reform, impact evaluation

\section{Introduction}

In the last decade, calls for reform of higher education in Romania also included suggestions for mergers of universities. Such experiences are rather rare in Romania (we have the case of the takeover of North University in Baia Mare by the Technical University of Cluj or the failed attempt to merge, also through a takeover, of the Eftimie Murgu University from Reșița by the West University from Timișoara) and 
occurred against the background of financial difficulties of small-sized universities.

Even if in the discourse of educational policy the topic of university mergers is still a dormant one, it will surely come back on the agenda when a combination of crisis and reforming impetus will generate a renewed search for solutions.

Experiences of mergers and of consequently reducing the number of universities were identified, in the last two decades, in the literature (Aarrevaara \& Dobson 2016; Aula \& Tienari 2011; Clark 2005; Evans 2015; Geschwind, Melin, \& Wedlin 2016; Hansen 2010; Harkin \& Hazelkorn 2014; Harkin \& Hazelkorn 2015; Harman \& Meek 2002; Huang 2000; Lang 2003; Nokkala \& Välimaa 2017; Salmi 2009) in China, France, England, the US, Denmark, Finland, Sweden or Ireland.

The cases or analyses identified in literature show that the merger is strongly supported by the states carrying out higher education reform programmes (the case of Ireland, Denmark, China or France). In such cases, the universities merge more or less voluntarily, often strongly motivated by the stimuli promised by the government (Huang 2000; Salmi 2009). However, the merger can also be the result of local initiatives, which aim at obtaining benefits, such as economies of scale, such as the case of the more or less friendly mergers in Sweden (Karlsson \& Geschwind 2016), which show that, just as in the case of corporations, mergers can be friendly (advanced collaborations) or hostile (takeovers). Moreover, when it is to be found within a reform wave, the merger is often just a detail alongside changes regarding university management, academic governance, study programmes funding or concentrating resources in excellence centres or in consortia (Salmi 2009). This short articles attempts to analyse the opportunity of a number of initiatives of mergers in Romanian higher education starting from a brief review of the international experience in the field and from the current state of tertiary education in Romania.

\section{Arguments in favour of mergers}

Two phenomena explain, on one hand, and justify, on the other, the need identified at the level of management of higher education systems for concentrating the supply of higher education diplomas: 
The massification of higher education, a phenomenon with numerous perverse consequences, generated endogenously by the quantitative and qualitative excesses of the supply (the best comparison model is the one of the real estate bubble, and the consequence could be a loss of credibility on long term for higher education diplomas). Inflation of university supply has lead, as it is well known, to suboptimal social effects: loss of diploma value and decrease in the quality of instruction on one hand, and unjustified and unbearable costs of public higher education systems, on the other.

The globalisation of the educational services market at tertiary level and of research, a phenomenon which is partly connected with the one above. All international rankings of universities only prove that a university is "better" the more "international" it is, namely it takes part at a global level in the competition for people, funding and recognition. Such an invasion creates further pressure on the marginal areas of the market, whose access to world-class research resources is almost impossible.

From here follow the main aims of some university merging programmes: Decreasing costs for supplying higher education programmes by reducing the number of administrative positions, sharing some facilities, eliminating double or parallel programmes by uniting common study programmes, etc.

Fighting against the educational oversupply and, consequently, against all its unfavourable consequences on higher education and on the value of the diplomas;

Improving their position in some international rankings, where they take advantage of the fact that these do not weigh their scientific performance indicators against the number of students or members of the academic body.

\section{Merger impact: the international experience}

The literature does not include many details on the results of these organisational operations, in relation to their objectives. It rather holds back regarding the evaluation of the impact of various merger operations, most analyses concentrating on the process rather than on the results (Aarrevaara \& Dobson 2016; Karlsson \& Geschwind 2016; 
Nokkala \& Välimaa 2017; Pruvot, Estermann \& Mason 2015). Naturally, the Chinese programme of halving the number of their universities is a success - only its success is discussed in an article by an author from the Popular Republic (Huang 2000)!

Yet there is already a certain convergence of the conclusions regarding the net results of mergers, experiences of such type being numerous enough and with enough spread through time in order to allow for such evaluations.

The merger seen as having limited aim and being insufficiently prepared may encounter many, and sometimes unexpected, difficulties. According to Salmi, the French grouped universities from the same territory around a Grand Ecole, which lead to the desired increase in the score in the Shanghai ranking, but did not manage to solve other problems deriving from the poor management of their higher education system (Salmi 2009: 44).

The article referenced lays the blame with the lack of assimilation of reciprocal organisational cultures, as well as the financial and social difficulties that the merger brings along. Also from France, we have a positive example of joint institutional production of several Grand Ecoles, of Paris I University and of CNRS who created, jointly, an economic sciences school - Paris School of Economics, after the model of the famous LSE. But here it is rather a consortium than a fusion, and the case could be analysed in depth by all those who seek such undertakings. Salmi also offers the 2008 example of two universities from Manchester that merged forming the new University of Manchester, in order to reduce costs. However, their deficits were not reduced following the merger, because making the educational offer and the staff more efficient could not be achieved completely, while the expenses were further increased by the investment made with the view of transforming the new institution in a pole of excellence in research (see, for this example, also Clark 2005). The World Bank's rapporteur has positive prognosis for the efforts carried out in Denmark, where the mergers were accompanied by management and academic governance measures considered adequate. However, Hansen (2010) does not share fully the optimism of the World Bank's specialist.

One of the almost general conclusion of the studies on the impact of university mergers is that they lead to the consolidation and development of the academic offer of the new entity, the students being 
offered more numerous and diverse study programmes, as well as richer support and student services (Gamage 1992; Harman \& Harman 2003; Wan \& Peterson 2007). The same studies show that the new higher education institutions enjoy better recognition, a higher visibility and a better positioning on the market, all these being facilitated by efficient branding strategies, when applied (Geschwind et al. 2016; Harkin \& Hazelkorn 2015).

On the other hand, many of the promises accompanying the merger efforts are not materialised when evaluating results. Studies generally agree that the expected economies of scale are not achieved. On the contrary, the merger usually comes with an increase in costs (Gamage 1992; Harman \& Harman 2003; Wan \& Peterson 2007). And no organisational, cultural or educational synergies appear: the Australian mergers have not lead to an improvement of teaching in the departments that were initially rated more poorly (Gamage 1992), the coloured students integrated in the historically white South African universities have not felt an improvement of their status (De Beer, Smith \& Jansen 2009) and generally the merger process is accompanied by a high level of stress for the staff of the universities involved (Evans 2015; Karlsson \& Geschwind 2016).

Another reason for mergers - improving the position in the international rankings that do not take into account the size of the institutions (such as ARWU - Shanghai) is met only under certain conditions. Simulations for the case of the French universities show that, according to the chosen combination of institutions, the results can be spectacular or disappointing (Docampo, Egret \& Cram 2015).

\section{The situation in Romania and the feasibility of possible mergers}

All of the above are highly relevant stakes for Romanian higher education nowadays, especially for the public institutions. In what these are concerned, as noticed by all realistic analyses, there is a chronic efficiency problem, which requires the questioning of the legitimacy of investment in Romanian state-owned universities. The indicators of the retardation of Romanian universities have been repeated obsessively, a situation made worse in the last two years by the entrance on the educational market of the first generations born after 1990, which lead 
to institutional diversification, massification and decrease of selectivity (Andreescu et al. 2012; Deca 2015; Hatos \& Pop 2015).

The bleak conditions of Romanian higher education stated above point rather clearly to the issue, namely the uncontrollable competition from the atomised population of universities, but also show the limited character of mergers as a solution. Mergers or consortia may regularize the behaviour of institutional actors through agreements between them, may bring economies of scale, even though the international experience is not encouraging, but cannot prevent the drifting of those that do not take part in such constructions; consequently, the efficient action of some market regulation structures (such as ARACIS, but without its obvious conflicts of interests) remains fundamental.

The merger, and its soft version, the consortia, are collective actions in the most economic meaning of the term. The economic and quality advantage of university union - the public good produced by these cooperatives - derives partly from the fact that these may impose a local control of a monopolist type on supplying of higher education (for many potential students, the changing of their residence town is not an easy option so that they are captive clients of universities from their proximity). It is a benefit of what Harkin and Hazelkorn (2015) call the new regionalism.

A consortium or a union of universities, which is not subjected to great competition pressure, may increase fees as well as raise requirements when selecting or evaluating students, both during their studies and when awarding degrees, without the fear of losing students. Naturally, such collective action does not have real chances of success if, outside of it, there are many institutions who disregard the rules, the Gordian knot of such an endeavour being, at the end of the day, the bringing together of all institutions of higher education from a certain area of recruitment into a single coalition. In Oradea, for instance, which is a university centre situated at a respectable distance from the others in the region (Arad, Timișoara, Cluj, Baia Mare) a common policy regarding the fees and quality could yield quick benefits for the four local institutions (University of Oradea, Emanuel Institute, Agora University and Partium University) by avoiding fee and selectivity auctioning.

However, nothing guarantees, for instance, that controlling the number of study programmes resulting from the amalgamation - 
another presumptive advantage - will not be compensated on the market by endless entrepreneurial initiatives which will cover the temporary deficit in the educational offer resulting from the merger. The objective of fighting against the educational oversupply is not sustainable unless the mechanisms for authorising study programmes become more restrictive than they had been before the exacerbation of the massification of higher education. Replacing two competing programmes in juridical sciences with a single one supplied in two locations but with the joint use of some resources will not be useful if, for instance, those academics who would be potentially unhappy with being made redundant following the efficiency measures accompanying the merger would start a new university endeavour with a parallel offer, probably at an unmatchable price. It is clear that the oversupply of higher education diplomas and the dumping - practiced most often by some private institutions that do not aim to be recognised or to have public support - will only be stopped through external, unequivocal interventions.

\section{Necessary precautions}

The merger can be promising and luring for some university leaders because it is a typical example of a shock strategy. Underperforming study programmes or higher education institutions may be dissolved during such evolutions and the merger can be the moment for radical change in the institutional structure of higher education. Obviously, such situations are also opportunities for abuse and unwanted developments. Consequently, all stages of institutional reform require maximum transparency in setting objectives, of the solutions and in implementing them, an endeavour that does not resonate fully with the idea of radical reform. The permanent exercise of negotiation and compromise required in order to not jeopardize the merger limits, however, as suggested by the analyses of the cases from France or Manchester, the results of the amalgamation to the extent of making the opportunity of this re-organisation debatable.

The premise that reuniting people and buildings under the same administrative umbrella will bring in itself an advantage when it comes to performance in research is also debatable, other than just summing 
them together and "bypassing" the international rankings, which are not relativized enough to take into account the number of researchers or students. Such tricks cannot possibly have sustainable effects when it comes to scientific productivity. Two mediocre researchers do not one better researcher make, and "concentrating resources" is just a good fetish to invoke in meetings. University coalitions must create added value of the type of joint investment in laboratories, publishing houses or libraries, of complementary project teams, in building excellence study and research programmes (such as Paris School of Economics) or through joining the international networks of researchers and by vigorously supporting the participation to funding competitions. Carrying out major organisational reform efforts, of the extent of amalgamations, only to obtain a better position (by a number of places) in international rankings with debatable validity is also a debatable option.

Increasing the selectivity of study programmes and of the universities is, without a doubt, a wish to which mergers and control over accreditation can contribute in a positive manner. Such a result, however, has to also be judged from the point of view of social justice, because the mere increase of the difficulty of access to higher education and to diplomas will impact mainly the candidates coming from disadvantaged backgrounds. Access to higher education is already a business from which entire categories of young people are excluded and, moreover, the indicators of quality and prestige of universities or of the study programmes are correlated too much with the level of instruction and the wallets of the students' parents. Thus, it becomes mandatory that mergers and consortia are judged as well from the perspective of the effects on the distribution of access opportunities to higher education, equal opportunities local or national policies being mandatory. If these are missing, the quality advantage will be eroded by the negative social effects of the polarised access to higher education positions.

However, from this perspective, mergers can even become a solution to decreasing inequity of access to quality education deriving from the co-existence of higher education institutions that are informally or formally stratified - by reputation or even by official rankings - and which have a vicious-circle type of effect, by reproducing the status inequalities. Amalgamation of universities from the "inferior" 
category within a comprehensive institution alongside nuclei of excellence in teaching and research may produce a benefit for the students from disadvantaged categories who should enjoy an improved reputation of universities, but also access to better quality resources of the enlarged structure. Here an important role could be held by the initiatives of diversification of study offers (recognition of prior learning and non-traditional study forms) that meet the needs of the nontraditional students. As the case from South Africa shows, initiatives of this type must be carefully planned and guided in order to avoid producing mere structures of reproducing inequality.

\section{Instead of conclusions}

University mergers, as well as amalgamations - another specimen from the kingdom of the coalition meant to manage the "educational bubble" - may be timely for the sustainable generation of a number of benefits from the point of view of economic efficiency, scientific productivity and educational quality, but especially from the point of view of availability of a number of quality academic programmes and services for an extended number of students - if they are accompanied by a number of institutional components:

Supporting an efficient mechanism of regulating the educational services supply in the tertiary sector (mandatory international accreditation of universities would be one possible solution).

Preferential support of those university coalitions that prove that they can attain significant savings, other than the reduction of administrative costs and that they are committed to investing in joint research and teaching structures of excellence.

Support for the coalitions that propose comprehensive policies for equal opportunities and support for disadvantaged categories. Truly synergic initiatives must be supported, which lead to the joint use of quality resources and which diversify creatively the educational offer, in order to deliver quality educational services in an efficient manner to as many students as possible, both of the traditional as well as nontraditional type. 
20 Journal of Research in Higher Education • Vol. I, No. 1

\section{References}

Aarrevaara, T., \& Dobson, I. R. (2016). "Merger mania? The Finnish higher education experience". Mergers in Higher Education, Springer, pp. 59-72.

Andreescu, L., Gheorghiu, R., Proteasa, V., \& Curaj, A. (2012). "Institutional diversification and homogeneity in Romanian higher education: the larger picture". European Higher Education at the Crossroads, Springer, pp. 863-885.

Aula, H., \& Tienari, J. (2011). "Becoming "world-class"? Reputationbuilding in a university merger". Critical perspectives on international business, 7(1): 7-29.

Clark, M. (2005). "Choosing not to converge: a case study of Manchester University". Managing Academic Support Services in Universities: the Convergence Experience: 152.

De Beer, J., Smith, U., \& Jansen, C. (2009). "'Situated' in a separated campus-Students' sense of belonging and academic performance: A case study of the experiences of students during a higher education merger". Education as Change. 13(1): 167194.

Deca, L. (2015). "International norms in the reform of Romanian higher education: a discursive analysis". European Journal of Higher Education, 5(1): 34-48.

Docampo, D., Egret, D., \& Cram, L. (2015). "The effect of university mergers on the Shanghai ranking". Scientometrics, 104(1): 175191.

Evans, L. (2015). "The worst of times? A tale of two higher education institutions in France: their merger and its impact on staff working lives". Studies in Higher Education: 1-19.

Gamage, D. T. (1992). "Recent reforms in Australian higher education with particular reference to institutional amalgamations". Higher Education, 24(1): 77-92.

Geschwind, L., Melin, G., \& Wedlin, L. (2016). "Mergers as Opportunities for Branding: The Making of the Linnaeus University". Mergers in Higher Education, Springer: 129-143. 
Hansen, H. (2010). "University Reforms in Denmark and The Challenges for Political Science". European Political Science.

Harkin, S., \& Hazelkorn, E. (2014). Restructuring Irish Higher Education Through Collaboration and Merger.

Harkin, S., \& Hazelkorn, E. (2015). "Institutional mergers in Ireland". Mergers and Alliances in Higher Education. Springer: 105-121.

Harman, G., \& Harman, K. (2003). "Institutional mergers in higher education: Lessons from international experience". Tertiary Education \& Management, 9(1): 29-44.

Harman, K., \& Meek, V. (2002). "Introduction to special issue: Merger revisited: international perspectives on mergers in higher education". Higher Education, 44(1): 1-4.

Hatos, A., \& Pop, A. (2015). "Evoluţia selectivităţii învăţământului superior din România sub impactul expansiunii şi contracţiei. 0 analiză descriptivă". Romanian Sociology/Sociologie Românească: 13.

Huang, H. (2000). "College and university mergers: impact on academic libraries in China". College \& Research Libraries, 61(2): 121.

Karlsson, S., \& Geschwind, L. (2016). "Takeovers in Swedish Higher Education: Comparing the «Hostile» and the «Friendly»". Mergers in Higher Education, Springer: 145-159.

Lang, D. (2003). The Future of Merger What Do We Want Mergers To Do: Efficiency or Diversity? The Canadian Journal of Higher Education, 33(3): 19-46.

Nokkala, T., \& Välimaa, J. (2017). Finnish mergers: Change in the Context of Continuity Policy Analysis of Structural Reforms in Higher Education, Springer, pp. 225-244.

Pruvot, E. B., Estermann, T., \& Mason, P. (2015). DEFINE thematic report: University mergers in Europe. Brussels: European University Association.

Salmi, J. (2009). The challenge of establishing world-class universities: World Bank Publications.

Wan, Y., \& Peterson, M. W. (2007). A case study of a merger in Chinese higher education: The motives, processes, and outcomes. International Journal of Educational Development, 27(6), 683696. 
